\title{
国内海面漁業と洋上風力発電
}

一産業連関表に基づく経済波及効果の検証一

\author{
望月 政志 (近畿大学) \\ 大石 太郎（福岡工業大学） \\ 八木 信行（東京大学）
}

\section{A Comparison of the Economic Ripple Effects of Marine Fisheries and Offshore Wind Power Generation through Input-Output Analysis}

\author{
Masashi Mochizuki (Kinki University) \\ Taro Oishi (Fukuoka Institute of Technology) \\ Nobuyuki Yagi (The University of Tokyo)
}

After the Great East Japan Earthquake, Japan has shown increased interest in renewable energy. While offshore wind power generation has attracted much attention in Japan because of the extensive ocean area available for the purpose, a tradeoff between policy support for offshore wind power and ocean fisheries is inevitable. We compare the economic ripple effects of investments in offshore wind power generation and marine fisheries using input-output

\section{1. はじめに}

2011 年 3 月 11 日の東日本大地震による原発事故 以来, 原発依存からの脱却と再生可能エネルギーを 用いたエネルギー代替の可能性, レジリアントなエ ネルギーの在り方が注目されている. そらした中で, 世界第 6 位の排他的経済水域を有する我が国に沶い ては海洋再生エネルギーへの期待も大きく，中でも 洋上風力発電は, 大きなポテンシャルを有すること が指摘されている ${ }^{1)}$. 最近では，同じ海面を利用す る漁業と洋上風力発電の共存共栄についても検討さ れてはいるものの, 現時点では洋上風力発電所建設 に伴ら漁業への影響は不明である ${ }^{2)}$.

他方, 漁業の盛んであった被災地では, 被災した 漁業の復興を目指すのか, あるいは洋上風力発電を 通じて再生可能エネルギーを提供していくべきかに ついて，補助金等を通じた政策的意思決定をどのよ らに進めていくのか明らかにすることが求められて いる. analysis. Our results show that investment in marine fisheries has a higher economic ripple effect than that in offshore wind power generation and that the annual economic value generated by the former is also higher. While offshore wind power is important as a source of alternative/clean energy for Japan, it would be prudent to realize its lower economic value compared to ocean fisheries.

そらした状況において，国内における洋上風力発 電の経済波及効果に関する分析は政策的判断をする 上で重要と思われるが，既存研究ではほとんど行わ れていないまた, 先駆的研究である松本・本藤 [3] では産業連関表を用いた風力発電の経済波及効果の 分析を行っているが，洋上風力と陸上風力を区別し て抢らず，雇用効果のみの分析に留まっている。 た，被災地での洋上風力発電に関する経済波及効果 については, 石川他 [4] が洋上風力発電による生 産額からみた東北地域（岩手，宮城，福島）での経 済波及効果の分析を行っているが，洋上風力発電所 建設による直接投資によって生み出される経済波及 効果に関する分析は行われていない.

そこで本研究では, 今後の震災復興に打ける洋上 風力発電や漁業振興への政策的意思決定に資する情 報提供を行らことを目的として, 以下の分析を行う.

第一に，洋上風力発電所建設拈よび建設に向けて の計画や建設後のメンテナンス等を含むコストを洋 
上風力発電所設置への投資とみなし，その投資から 生み出される経済波及効果を全国レベル打よび地域 レベルで試算する。全国レベルでは，「平成 17 年 （2005 年）産業連関表」（総務省 [5]）を用いた全 国での経済波及効果を試算し，国内にて洋上風力発 電所を設置した場合の一般的な経済波及効果につい てみる，地域レベルでは，海面漁業に扔ける被災漁 船の被害額が全国で最も大きかった宮城県を事例に 取り上げ，宮城県で洋上風力発電所設置に投資した
場合の経済波及効果について「平成 17 年宮城県産 業連関表」（宮城県［6]）を用いて試算する.

第二に，震災復興に向けて被災漁船の修復・建 造のための設備投資を行った場合の経済波及効果 と同等の投資を洋上風力発電に対して行った場合 の経済波及効果を金額べースで試算し，両者の比 較を行った.

第三に，洋上風力発電所が生み出す経済価値（年 間発電金額）を試算した。また，宮城県の被災漁船

\section{表 1．洋上風力発電所設置に係るコストと産業連関表の対応部門}

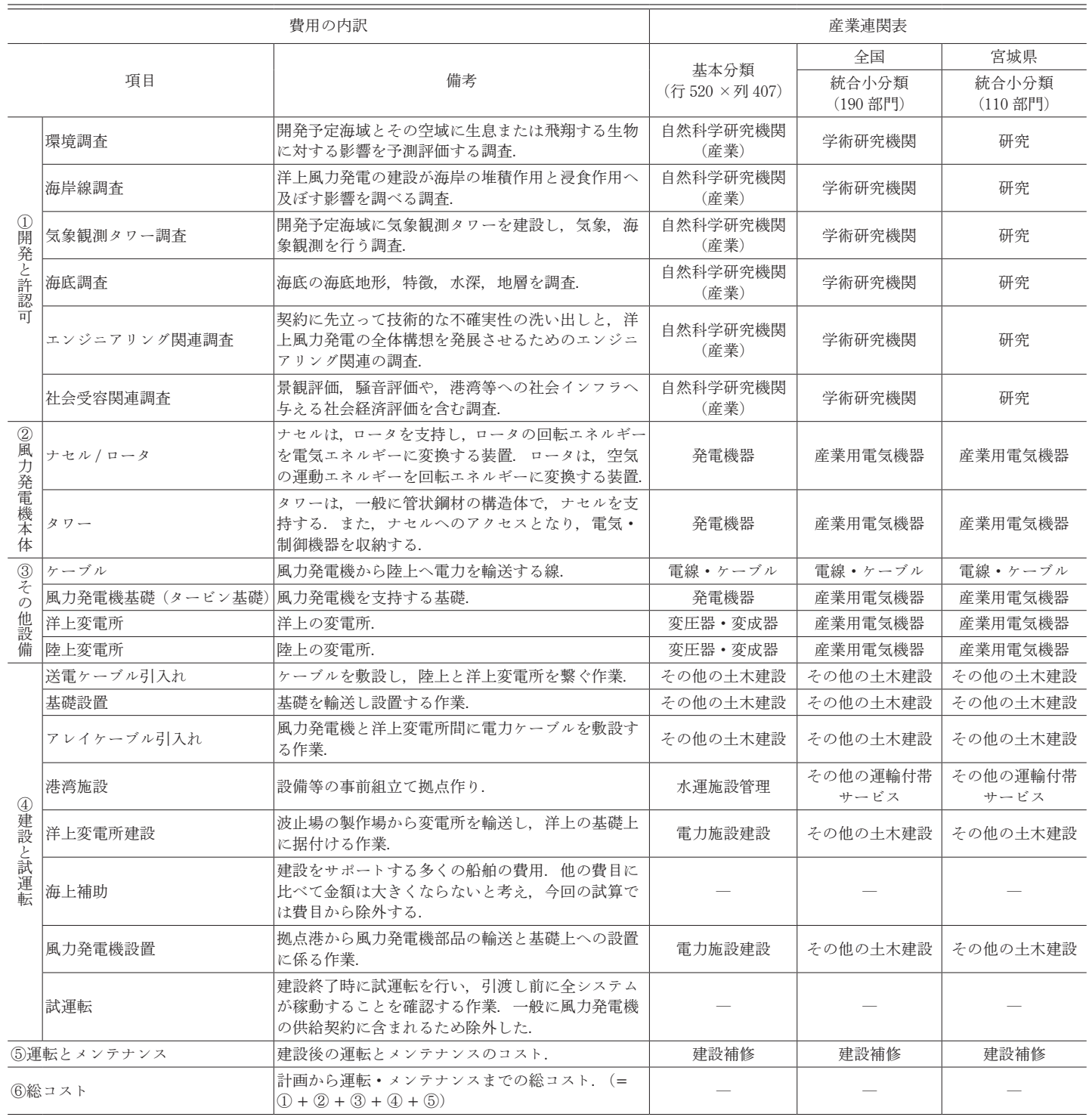

注：1）出所：渡邊・中尾 [9] の費用項目就よび総務省 [5], 宮城県 $[6]$ の産業連関表より筆者作成. 
の修復・建造によって生み出される経済価值（海面 漁業生産額）についても試算し，洋上風力発電から と被災漁船の修復・建造から生み出される経済価值 についても比較した.

なお，洋上風力発電の基礎設置形式には，設置海 域の水深の違い等により，風車を海底に固定させる 着床式と風車自体を海に浮かべる浮体式の設置形式 があるが 3，現時点では着床式が主流でありデータ が充実していることから，本稿では着床式の洋上風 力発電を想定し試算した.

\section{2. 洋上風力発電の経済波及効果}

（1）計画・建設・メンテナンス等に係るコストと産 業連関表の対応部門の分類

洋上風力発電への投資による経済波及効果を導く ためには，洋上風力発電の計画・建設・メンテナン ス等に係るコストの内訳別に産業連関表の対応部門 の分類を行ら必要がある. しかし, 日本の洋上風力 発電ははじまったばかりで国内資料に基ついてコス トに関するデータを入手することが困難である。そ
こで洋上風力発電の先進国であるイギリスの政府系 特殊法人が洋上風力発電への理解を促進するために 発行したガイドブック「An Guide to an Offshore Wind Farm」（BVG Associates [8]）とその邦訳版である渡 邊・中尾 [9] に記載されている洋上風力発電建設 等にかかる費用項目を用いて ${ }^{4)}$, 各項目内容に応じ て総務省［5］の 190 部門表と宮城県［6］の 110 部 門表の基本分類，統合小分類に対応する部門の分類 を行った（表 1 ）。

\section{（2）洋上風力発電の経済波及効果}

表 2 は，全国拈よび宮城県での洋上風力発電所設 置による経済波及効果の試算結果を示している，表 2 の費用の割合は，渡邊・中尾 [9] に記載されて いる洋上風力発電所設置に要する項目毎の費用（金 額）を総コスト（金額）で除した值である。渡邊・ 中尾 $[9]$ に打けるイギリスの值を用いた理由として, 「洋上風力発電の技術革新は, 現在も急ペースで進 行中」（渡邊・中尾 [9]）であり，今後採用される コストを正確に把握することは困難であるため，今 回は最新の技術を想定した参考値として渡邊・中尾

\section{表 2. 全国および宮城県での洋上風力発電所設置による経済波及効果の試算結果}

\begin{tabular}{|c|c|c|c|c|c|c|c|}
\hline & \multirow{2}{*}{ 項目 } & \multirow{2}{*}{$\begin{array}{c}{\text { 費用の割合 }{ }^{1)}}_{\text {【A】 }}\end{array}$} & \multicolumn{2}{|c|}{$\begin{array}{l}\text { 産業連関表の逆行列係数 } \\
\text { (列和) }\end{array}$} & \multirow{2}{*}{\begin{tabular}{|c} 
国産品需要率 \\
$(\%)$ \\
【D】
\end{tabular}} & \multicolumn{2}{|c|}{ 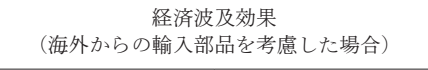 } \\
\hline & & & $\begin{array}{l}\text { 全国 }^{3)} \\
\text { 【B】 }\end{array}$ & $\begin{array}{l}\text { 宮城 } 4 \text { ) } \\
\text { [C】 }\end{array}$ & & 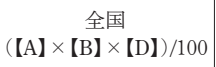 & $\begin{array}{c}\text { 宮城 } \\
(\text { 【A】 } \times 【 \mathrm{C} 】 \times[\mathrm{D} 】) / 100\end{array}$ \\
\hline \multirow{5}{*}{$\begin{array}{l}\text { (1)開発と } \\
\text { 許認可 }\end{array}$} & 環境調査 & 0.0025 & 1.846 & 1.458 & 100 & 0.005 & 0.004 \\
\hline & 海岸線調査/気象観測タワー調査 & 0.0282 & 1.846 & 1.458 & 100 & 0.052 & 0.041 \\
\hline & 海底調査 & 0.0056 & 1.846 & 1.458 & 100 & 0.010 & 0.008 \\
\hline & エンジニアリング関連調査 & 0.0006 & 1.846 & 1.458 & 100 & 0.001 & 0.001 \\
\hline & 社会受容関連調査 & 0.0001 & 1.846 & 1.458 & 100 & 0.000 & 0.000 \\
\hline \multirow{2}{*}{$\begin{array}{l}\text { (2)風力発 } \\
\text { 電機本体 }\end{array}$} & ナセル/ロータ & 0.3085 & 2.188 & 1.346 & 30 & 0.203 & 0.125 \\
\hline & タワー & 0.0617 & 2.188 & 1.346 & 0 & 0.000 & 0.000 \\
\hline \multirow{4}{*}{$\begin{array}{l}\text { (3)その他 } \\
\text { 設備 }\end{array}$} & ケーブル & 0.0494 & 1.990 & 1.277 & 100 & 0.098 & 0.063 \\
\hline & 風力発電機基礎（タービン基礎） & 0.1851 & 2.188 & 1.346 & 100 & 0.405 & 0.249 \\
\hline & 洋上変電所 & 0.0185 & 2.188 & 1.346 & 100 & 0.040 & 0.025 \\
\hline & 陸上変電所 & 0.0247 & 2.188 & 1.346 & 100 & 0.054 & 0.033 \\
\hline \multirow{6}{*}{$\begin{array}{l}\text { (4) 建設と } \\
\text { 試運転 }\end{array}$} & 送電ケーブル引入れ & 0.0494 & 1.988 & 1.391 & 100 & 0.098 & 0.069 \\
\hline & 基礎設置 & 0.0617 & 1.988 & 1.391 & 100 & 0.123 & 0.086 \\
\hline & アレイケーブル引入れ & 0.0370 & 1.988 & 1.391 & 100 & 0.074 & 0.051 \\
\hline & 港湾施設 & 0.0053 & 1.528 & 1.372 & 100 & 0.008 & 0.007 \\
\hline & 洋上変電所建設 & 0.0062 & 1.988 & 1.391 & 100 & 0.012 & 0.009 \\
\hline & 風力発電機設置 & 0.0864 & 1.988 & 1.391 & 100 & 0.172 & 0.120 \\
\hline \multicolumn{2}{|c|}{ (5)運転とメンテナンス } & 0.0682 & 2.042 & 1.302 & 100 & 0.139 & 0.089 \\
\hline \multicolumn{2}{|l|}{ (6)総コスト } & 1 & - & - & - & 1.494 & 0.980 \\
\hline
\end{tabular}

注：1）費用の割合は，渡邊・中尾 [9] 飞記載されている洋上風力発電所設置に要する項目毎の費用（金額）を総コスト（金額）で除した值である。

2）風力発電機本体のパーツに打いて海外からの輸入部品が多く使わ机ている国内の風力発電の現状を考慮し，松本・本藤 [3] から風力発電機本体 のナセル/ロータの国産品需要率を 30\%（70\%を海外から輸入），タワーの国産品需要率を 0\%（100\%を海外から輸入）と仮定している。

3）全国の産業連関表の逆行列係数については, 総務省 [5]の 190 部門表の列和の值を用いた。

4）宮城の産業連関表の逆行列係数については, 宮城県 [6] の 110 部門表の列和の値を用いた。 
［9］の值を用いた.

経済波及効果の試算方法は，以下の通りである. 表 1 で区分した産業連関表に対応する総務省 [5] 抢よび宮城県 [6]の逆行列係数（列和）(【B】, 【C】) と国産品需要率 (ID】)を各コストの費用の割合 (【A】) に乗じて 100 で除したコスト別の経済波及効果を試 算し, 試算したコスト別の経済波及効果の総和を総 コストの経済波及効果（発電所 1 施設を建設するの に要する費用に対比させた経済波及効果）とした。

経済波及効果を試算するにあたって，移入を考慮 した逆行列係数 $[\mathrm{I}-(\mathrm{I}-\mathrm{M}) \mathrm{A}]^{-1}$ を使用している。また， 風力発電機本体のパーツとして海外からの輸入部品 が使用されている国内の風力発電の現状を考慮し, 松本・本藤 [3] が推計した值から風力発電機本体 のナセル/ロータの国産品需要率を 30\%（70\%を海 外から輸入), タワーの国産品需要率を $0 \%(100 \%$ を海外から輸入）と仮定し, 海外からの輸入部品を 考慮した経済波及効果とした.

表 2 から, 洋上風力発電所 1 施設を建設するのに 要する費用に対比させた経済波及効果は, 全国が 1.494, 宮城県が 0.980 となった. この結果から, 全 国レベルでは洋上風力発電設置による経済波及効果 は投資額の約 1.49 倍の経済波及効果が期待できる が，宮城県では約 0.98 倍の経済波及効果しか期待で きず，地域への経済波及効果をあまり期待できない ことがわかった：ここで宮城県の経済波及効果が 1 を下回った要因として, 前述したように輸入部品に 頼っている風力発電機本体のパーツに対する需要が 国内ではなく海外へと流出したことが挙げられる.

\section{3. 漁船への設備投資による経済波及効果}

次に, 被災した宮城県内の海面漁業の漁船復旧に よる地域への経済波及効果と宮城県で洋上風力発電 所を設置した際の経済波及効果について比較する。
宮城県［6］の 110 部門表より，漁船の建造・修 理が含まれる産業部門「船舶・同修理」の逆行列倸 数（列和）が 1.36 であることから，宮城県内の被 災漁船の復旧に対する設備投資 1 単位あたりの経済 波及効果は 1.36 と捉兄られる。したがって，前述 で試算した宮城県の洋上風力発電所設置の経済波及 効果が 0.98 であったことから，宮城県では同じ投 資額ならば洋上風力発電所に比べ被災漁船への復旧 に投資した方が，地域への経済波及効果が大きいと 言光る.

具体的な金額でみると次のようになる. 水産庁 $[10]$ によると，震災による宮城県の被災漁船数は 12,029 隻で，漁船被害額については 116,048 百万円であるこ とから，仮にこれらの漁船を復旧寸るために 116,048 百万円を投じて漁船の建造・修復をしたと仮定する と，宮城県の地域内一の経済波及効果は約 157,825 百万円（116,048 百万円 $\times 1.36 ）$ となる。他方，同 等の額を洋上風力発電所設置に投じた場合の経済波 及効果が 113,727 百万円 $(116,048$ 百万円 $\times 0.98)$ となることから，被災漁船への復興支援の方が洋上 風力発電への投資に比べて 44,098 百万円大きい経 済波及効果を地域に与えることがわかる.

また，全国レベルでみても，総務省［5］の190 部門表の「船舶・同修理」の逆行列係数（列和）よ り，漁船の建造・修理への投資 1 単位あたりの経済 波及効果は 2.497 であり, 洋上風力発電の経済波及 効果（全国）1.494よりも大きいことから，宮城県 と同様に，同じ投資額ならば洋上風力発電所に比へ て漁船の建造・修理に投資した方が経済波及効果は 大きいと言える.

\section{4. 経済価値}

\section{（1）被災漁船の復旧から生み出される経済価値}

表 3 は, 東日本大震災による国内海面漁業（養殖

\section{表 3. 被災漁船数と被災漁船の機会損失額}

\begin{tabular}{c|c|c|c|c|c}
\hline \hline & $\begin{array}{c}\text { 被莰漁船数 } \\
\text { (隻) }\end{array}$ & $\begin{array}{c}\text { 県内登録漁船数 } \\
\text { (隻) }\end{array}$ & $\begin{array}{c}\text { 海面漁業・養殖業生産額 } \\
\text { (百万円) }\end{array}$ & $\begin{array}{c}\text { 一隻当たりの生産額 } \\
\text { (百万円) }\end{array}$ & $\begin{array}{c}\text { 被㷋漁船の機会損失額 } \\
\text { (百万円) }\end{array}$ \\
\hline 宮城県 & 12,029 & 13,478 & 77,679 & 6 & 69,328 \\
\hline 全国 & 28,612 & - & 938,955 & - & 155,146 \\
\hline
\end{tabular}

注 : 1) 出所 : 水産庁 $[10]$, 水産庁 $[11]$, 農林水産省 [12] より筆者作成.

2）被災漁船の機会損失額は，一隻当たりの生産額（県内登録漁船数または漁船保険加入隻数で海面漁業・養殖業生産 額を除した值）に被災漁船数を乗じた值.

3）全国の被災漁船の機会損失額は，被災した各都道府県別の機会損失額を合計した值. 


\section{表 4. 着床式洋上風力発電における年間発電金額の 試算結果}

\begin{tabular}{l|c}
\hline \hline 総投資額 $($ 百万円 $)$ & 116,048 \\
\hline システム価格 $($ 万円 $/ \mathrm{kW})$ & 26.9 \\
\hline 発電容量 $(\mathrm{kW})$ & 431,405 \\
\hline 設備利用率 $(\%)$ & 27.27 \\
\hline 年間発電量 $(\mathrm{kWh)}$ & $1,030,563,185$ \\
\hline 年間発電金額 $($ 百万円 $)$ & 23,806 \\
\hline
\end{tabular}

注：1）システム価格の值は, 茨城新聞 $[13]$ より, ウイ ンド・パワーかみす洋上風力発電所に打ける 2012 年 5 月着工の増設工事（発電容量 $16,000 \mathrm{kw}$ ）の 総建造費約 43 億円から算出.

2）発電容量は，投資額をシステム価格で除した值

3）設備利用率については，一般社団法人日本風力発 電協会ロードマップ検討 WG [7] より，年間平 均風速 $7.0 \mathrm{~m} / \mathrm{s}$ のときの設備利用率の值を用いた.

4) 年間発電量 $=$ 発電容量 $\times 24$ 時間 $\times 365$ 日 $\times$ 設備 利用率

5）年間発電金額は，再生可能エネルギーの固定価格 買取制度・2012 年度設定価格（20 kw 以上）の 23.1 円 $/ \mathrm{kWh}$ を年間発電量に乗じた值.

業含む）の被災漁船数と被災漁船の機会損失額を示 している.

ここでいう機会損失額とは，被災漁船がダメージ を受けた状態のまま 1 年間漁業生産されなかった場 合に失われる年間生産額と定義する. 表 3 から，震 災によって全国で約 155,146 百万円，宮城県に扣い ては 69,328 百万円の機会損失額が発生することが わかる。

機会損失額について別の見方をすれば，被災した 漁船を被害額の 116,048 百万円を投じて稼働できる 状態にすれば，宮城県で年間 69,328 百万円相当の 国内海面漁業（海面養殖業も含む）からの経済価値 が見込まれるといらことでもある。

\section{（2）洋上風力発電から生み出される経済価値}

また，震災による宮城県の漁船の被害額 116,048 百万円と同等の金額を洋上風力発電に投資した場合 に生み出される経済価值（年間発電金額）について 比較した.

表 4 は，着床式洋上風力発電に拈ける年間発電金 額の試算結果を示している，ここでは，年間発電金 額を試算するため, ウインド・パワーかみす洋上風 力発電所に扣ける 2012 年 5 月着工の増設工事（発 電容量 $16,000 \mathrm{kw）}$ の総建造費約 43 億円から算出し たシステム価格 26.9 万円 $/ \mathrm{kW}$ を用いて試算した ${ }^{5)}$.
年間発電金額の試算方法は，以下の通りである.

(1) 投資額とシステム価格から発電容量を算出 する.

(2) (1)で求めた発電容量と設備利用率を使い, 以 下の式で年間発電容量を算出する. 年間発電量 $=$ 発電容量 $\times 24$ 時間 $\times 365$ 日 $\times$ 設備利用率

(3) (2)で求めた年間発電量に発電した電気の販売 価格を乗じる。

試算結果から年間発電金額は 23,806 百万円とな り，前述した漁船の建造・修繥による投資から得ら れる経済価値（69,328 百万円）に比べると，洋上風 力発電への投資から得られる経済価值（年間発電金 額）が低いことがわかった.

\section{5. まとめ}

本研究では，全国レベル拈よび地域レベル（宮城 県）に打ける洋上風力発電所設置による投資がもた らす経済波及効果を試算した結果，全国レベルでは 最大で投資額の約 1.49 倍の経済波及効果を得られ るものの, 地域レベル (宮城県) では最大でも約 0.98 倍の経済波及効果と小さいことが分かった.

また，宮城県に扣ける海面漁業の被災漁船に対す る震災復興への投資による経済波及効果や被災漁船 の復旧から生み出される経済価值および洋上風力発 電から生み出される経済価値を試算した結果，投資 が誘発する需要の側面（経済波及効果），投資が生 久出す価值の側面（経済価値）のいずれからも国内 海面漁業の漁船の建造・修復への投資の方が効果的 であるといら結果が得られた。

こうした分析結果から，洋上風力発電の経済パ フォーマンスは必ずしも高くないことが示唆され る，特に被災地である宮城県では，洋上風力発電を 通じた地域経済の復興より，被災漁船の復旧を通じ た地域経済の復興の方が効果的であるといえる。た だし，このことは，被災地での洋上風力発電所設置 に対して必ずしも批判するものではない，例えば， 地域への経済波及効果が小さいものの未利用漁場て の洋上風力発電による利用は，漁業と洋上風力によ る共存が図れ，漁業と洋上風力発電の多面的海面利 用による地域経済の活性化が期待できる。

最後に今回の分析で残されている課題について述 ベて扣く．今回行った地域レベルでの経済波及効果 
の試算については，宮城県のみを対象としており， 他の地域について子宮城県と同様の結果が得られる とは限らないため, 他の地域の分析については今後 の課題とする.

[付記] 本研究は, 総合地球環境学研究所の平成 24 年度インキュベーション研究 (IS) プロジェクト 「レジリアントなエネルギーシステムの構築に向け たシナリオ作成のための予備的研究」に打ける研究 成果の一部である.

注 1）高木 [1] を参照.

2）中原 [2] を参照.

3）浮体式については実用化に向けての実証実験が行 われている段階であるが, 一般社団法人日本風力 発電協会ロードマップ検討 WG［7］によると, 我 が国の洋上風力発電に利用可能な建設適地面積の 広さは, 着床式で $14,746 \mathrm{~km} 2$ であるのに対し, 浮 体式は77,443 km2 と大きく, 今後, 実用化されれ ば浮体式洋上風力発電のニーズが高くなることが 期待される.

4) BVG Associates [8] で試算されているコストは, 発電容量 $500 \mathrm{MW}(5 \mathrm{MW} \times 100$ 基）の着床式洋上 風力発電を想定した值である.

5）ウインド・パワーかみす洋上風力発電所から導出 したシステム価格 26.9 万円 $/ \mathrm{kW}$ は, 独立行政法人 新エネルギー・産業技術総合開発機構 [15]（p. 126）にあるイギリスの事例のシステム価格 31.0 万円 $/ \mathrm{kW}$ と大きな差はない.

\section{参考文献}

[1] 高木 健「海洋再生可能エネルギーの技術面 について」『2012 年度国際漁業学会大会シン ポジウム「再生可能エネルギーと水産業」報 告要旨集』, 2012.

[2] 中原裕幸「風力発電事業等と漁業との協調に ついて」『2012 年度国際漁業学会大会シンポ ジウム「再生可能エネルギーと水産業」報告 要旨集』, 2012.
［3］松本直也・本藤祐樹「拡張産業連関表を利用 した再生可能エネルギー導入の雇用効果分析」 『日本エネルギー学会誌』第 90 巻第 3 号, pp. 258-267，2011 年.

[4]石川良文・中村良平・松本 明「東北地域に 打ける再生可能エネルギ一導入の経済効果： 地域間産業連関表による太陽光発電・風力発 電導入の分析」『RIETI Policy Discussion Paper Series 12-P-014』, 2012.

[5]総務省「平成 17 年（2005 年）産業連関表」, 2009.

[6]宮城県「平成 17 年宮城県産業連関表」, 2010.

[7]一般社団法人日本風力発電協会ロードマップ 検討 WG「風力発電の賦存量とポテンシャル 扣よびこれに基づく長期導入目標とロード マップの算定 (Ver. 1.1)」, 2010 年.

[8] BVG Associates, A Guide to an Offshore Wind Farm, THE CROWN ESTATE, 2010.

[9] 渡邊文人 - 中尾 徹「洋上風力発電の計画 建設・運開・メンテナンスに係る費用等（洋

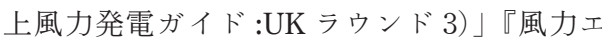
ネルギー』第 35 巻第 3 号, pp. 85-113， 2011.

[10] 水産庁「平成 23 年度水産白書」, http://www jfa.maff.go.jp/j/kikaku/wpaper/h23/

[11］水産庁『漁船統計表』総合報告第 63 号, 2011 .

[12] 農林水産省「平成 22 年漁業生産額」, http:// www.maff.go.jp/j/tokei/kouhyou/gyogyou_seigaku/ index.html

[13]『茨城新聞』「神栖洋上, 風力発電 8 基増設 1 万 6000 キロワット分来月着工」, 2012 年 4 月 28 日.

［14］環境省「平成 22 年度 再生可能エネルギー導 入ポテンシャル調査報告書」, 2011 年.

[15] 独立行政法人新エネルギー・産業技術総合開 発機構「NEDO 再生可能エネルギー技術白書」, 2010 年.

（受理日：2013 年 4 月 12 日） 